\title{
The Theoretical Impact Of The Listing Of Syariah-Approved Stocks On Stock Price And Trading Volume
}

Carl B. McGowan, Jr., Norfolk State University, USA

Junaina Muhammad, University Putra Malaysia, Malaysia

\begin{abstract}
The stock price and trading volume reactions of companies to single events, such as public announcements on mergers, dividend payments, or security issue announcements have been studied extensively. The impact of news about a continuing event such as the news on the inclusion in and exclusion of stocks from the KLSE Syariah Index that occurs twice yearly affects security prices and trading volume. This paper examines reasons that price and trading volume of Syariah-approved stocks might react to the inclusion-exclusion exercise. The selection criteria set by the Syariah Advisory Council of Securities Commission of Malaysia in updating the list of the Syariah-approved stocks is not based on the financial soundness alone. Views from Syariah perspective and from financial theories are discussed to support the behavior of the included and excluded stocks from the Kuala Lumpur Syariah Index.
\end{abstract}

Keywords: Syariah-compliant, stock price, trading volume, index effects

\section{INTRODUCTION}

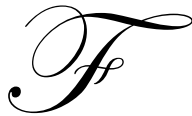

inance theory regards financial markets as sophisticated information processing systems (Kaen \& Tehranian, 1990). Empirical evidence has generally confirmed the efficient market theory predictions by showing that publicly released information is anticipated and rapidly incorporated into security prices. However, much empirical work has evaluated stock price reactions of companies to single types of events, such as public announcements on merger, dividend payments, or security issue announcements. Less attention has been directed to the question of how news about a continuing event, such as the news on the inclusion in and exclusion of stocks from the Kuala Lumpur Stock Exchange (KLSE) Syariah Index (KLSI) that occurs twice a year, affects the security prices and trading volume of the companies involved.

The selection criteria used to include and to exclude stocks from the KLSE Syariah Index (KLSI) is unique since it is based on Islamic Syariah ${ }^{1}$ law. Webley et al. (2001) claim that there has been an increase in the literature of economic theory than extends beyond simple optimality. In other words, economics has a moral dimension (Etzioni, 1988). Investors are not only concerned about what is profitable but also what makes their investments ethical. In the case of Malaysian investors, ethical investments for Muslims are investments in financial products that are approved under Islamic law (Syariah). Islam does not recognize the separation between spiritual and temporal affairs and considers commerce as a matter of morality that is subject to the precepts of the Syariah (Karim, 2001). Hence, due to the increasing awareness of Syariah-approved products, the Islamic Capital Market (ICM) has been established. The ICM refers to the market where the activities are carried out in ways that do not conflict with the conscience of Muslims and the religion of Islam. Today, various capital market products are available for Muslims who only seek to invest and transact in the ICM. Such products include the list of the Securities Commission's Syariah-compliant securities traded on Bursa Malaysia and is supervised by the Syariah Advisory Council (SAC) of the Securities Commission.

\footnotetext{
${ }^{1}$ The Islamic jurisprudence extracted from the holy Quran and Sunnah.
} 


\section{THE IMPACT OF SYARIAH ON EQUITY INVESTING}

Before going any further, a question must be asked. What is the relationship between investment and Islam? The Quran is a book of guidance containing general principles applicable to all times and places including those pertaining to investments. Implicitly, there is a direct link between investment and Islamic principles. According to Rosly and Zabidi (2002), Islam provides principles and guidance in investment transactions that should be implemented according to the teachings of Islam. Islamic investment principles are based on Syariah and ' $A \mathrm{ql}^{2}$ which include experiences that are all linked to each other and should not be separated. In Islam, one of the aims of the Syariah is to provide protection and benefits in general to the Muslim ummah (nation) and the country, in the following spheres: religion (deen), life (nasl), intellect ('aql), and family (nasl). The protection for wealth ( $\mathrm{mal}$ ) falls into one of the above spheres and to protect wealth, Islam allows business trading but forbids riba ${ }^{3}$. As stated in the Quran: "...God has permitted trade and forbidden usury. Those who after receiving direction from their Lord, desist, shall be pardoned for the past; their case is for God; but those who repeat the offence are Companions of the fire: they will abide therein forever" (2:275). Hence, the Quran regards business as lawful, good, and beneficial for both the individual and the society. Fair trade and honest business are praised, recommended, and strongly exhorted by the Quran. Wealth in Islam should not be exploited negatively or be contrary to Syariah principles. Thus, investment is one way to create wealth and its creation should not involve financial services based on riba, gharar (uncertainties), and the manufacture or the sale of non-halal (non-permissible according to Islam) products such as pork or alcohol as well as dealing in gambling activities or services. In equity investments such as shares traded on Bursa Malaysia, all these Islamic principles are applied to Syariah-approved counters.

The intellect ('aql) in Islam is supreme. It differentiates man from the other created living beings. According to Ibn Miskawayh, "God created Intelligence ('aql) and it is by it that the heavens and earth exists, and that the knowers and the world have been made to exist. Without it (intelligence), wisdom would not exist, knowledge would not be perceived, godhead would not appear, nor would divinity be known" (Rosly, 2005). When one abuses the intellect ('aql), he is also abusing public interest. So, when an investor behaves irrationally, it will not only hurt him alone, but also others and economic welfare. With 'aql, one should be able to differentiate what is permissible (halal) and what is forbidden (haram) according to Syariah Islam. Therefore, investment in the equity market such as stocks requires investors to be mindful about the Syariah requirements of investing in the financial assets. If buying the non-Syariah-compliant stock is forbidden (haram) according to Syariah Islam - the company directly and explicitly deals with prohibited goods and services, such as gambling, riba, prostitution, pornography, alcohol, pork and pork products, then the buying of Syariah-approved stocks constitutes an act of worship (ibadat) because the act is according to Syariah Islam. The act of avoiding the non-Syariah-approved stocks also constitutes an act of worship (ibadat) because Syariah tells us to avoid all prohibited goods and services and our 'aql would help us make the decision whether to follow the Syariah or not.

\section{THE HISTORY OF THE KLSE SYARIAH INDEX}

Over the last few years, differentiation based on Syariah-compliance has become a strategy of increasing importance to Malaysian companies in their business operations. Syariah-compliant stocks have always been associated with not only "halal" or lawful practices, according to the Syariah, but also related to good image $(\text { Toyyiba })^{5}$ in the physical context such as in quality, safety, environmentally friendliness, and process efficiency. The Syariah Advisory Council (SAC) of the Securities Commission (SC) plays an important role in certifying and updating the list of securities that have been classified as Syariah-approved securities twice a year, in April and October. This certification of Syariah-approved securities is done through the input and support received from the Security Commission ${ }^{6}$.

\footnotetext{
${ }^{2}$ Human intellect differentiates humans from animals and should be used to make decisions that benefit mankind.

${ }^{3}$ Usury or interest

4 "Eat of the things which Allah hath provided for you, lawful and good; but fear Allah, in Whom ye believe" (Al-Maidah: 88).

${ }^{5}$ An Arabic word which means goodness in the physical context.

${ }^{6}$ The Security Commission gathered information on the companies from various sources, such as company annual financial reports, company responses to survey forms and inquiries made to the respective management of the companies.
} 
The launch of the Kuala Lumpur Stock Exchange Syariah Index (KLSI) in April 1999 is to accommodate the increasing demand by local and foreign investors who seek to invest in securities and instruments that are copmplinat with Syariah principles. The KLSE Syariah Index serves the purpose of benchmarking the performance of Syariah-compliant counters. Bursa Malaysia has listed the KLSI since 1996 to represent the stocks that are Syariah-compliant. The SAC has applied a standard criterion in focusing on the activities of the companies listed on Bursa Malaysia. As such, subject to certain conditions, companies whose activities are not contrary to the Syariah Principles will be classified as approved securities. On the other hand, companies will be classified as non-approved securities if they are involved in any of the following core activities: financial services based on riba (interest); gambling; manufacture or sale of non-halal products or related products; conventional insurance, entertainment activities that are non-permissible according to Syariah; manufacture or sale of tobacco-based products or related products; stockbroking or share trading in Syariah non-approved securities; and other activities deemed nonpermissible according to Syariah (List of Securities Approved by SAC of SC, 2006).

KLSI serves the purpose of benchmarking the performance of Syariah-compliant counters. Thus, as an emerging Muslim country that offers a wide range of Islamic financial products ${ }^{7}$, Malaysia can benefit from developing domestic financial markets by incorporating the issue relating to Syariah-compliant stocks behavior and performance. Syariah-compliant counters are selected and screened by the SAC twice a year, April and October, in which Syariah guidelines or criteria precede any environmental or social analysis of corporate performance. The KLSI is based on all Syariah-compliant shares that are listed on the Main Board of KLSE and Mesdaq. As of May 27, 2007, the KLSI included a total of 886 (more than 86.1\%) Main Board shares that were on the list of Securities Commission's Syariah-approved securities and the total increased over the listing period from 1997 to 2003 . Since the introduction of the KLSI in April 1999, the components of the KLSI have also been updated regularly to reflect the changes to the SAC list.

The rest of the paper discusses the theoretical behavior of Syariah-approved stock performance according to financial theories and perceptions about Syariah-approved stocks. The theories and perceptions are discussed in view of the share price and trading volume movement of the Syariah-approved stocks as a result of the inclusionexclusion exercise from the Kuala Lumpur Syariah Index (KLSI) in every April and October each year.

\section{FUND MANAGER VIEWPOINT}

With more than $80 \%$ of the stocks listed on Bursa Malaysia are classified as Syariah-approved securities by the SAC, the KLSI provides guidance valuable to the investing public and important for the development of the Islamic investment management industry. This is clearly reflected in the continued increase in the number of Syariah-based unit trust funds over the past few years. The list of Syariah-approved securities facilitates the development of Syariah-based unit trust funds by providing necessary means for Muslim investors who prefer their investment to be managed professionally.

Fund managers of Syariah-based unit trust funds are particularly interested in the composition of the constituent stocks of the KLSI. If fund managers perceive that a stock that is announced to be included in the index is likely to perform well in the future, the fund managers will buy this stock. Similarly, an announcement that a stock is to be removed from the index will cause fund managers to sell the stock. Thus, a change in the KLSI composition will induce fund managers to take action according to Syariah guidelines. Therefore, funds managers' action is likely to influence the demand for stocks that are included and excluded from the Syariah index. Since the early 1990s, the number of Syariah-based unit trust funds has grown steadily. As shown in Exhibit 1, by July 2007 the number of Syriah-based unit trust funds has increased to 478 funds, with total net asset value (NAV) and total units in circulation amounting to RM 153 billion and 181 billion units, respectively.

\footnotetext{
${ }^{7}$ Since the 1960s, investors seeking investment opportunities consistent with Islamic principles have done so through the Pilgrims Fund Board (Lembaga Tabung Haji) followed by the inception of Bank Islam Malaysia in 1983 then by the establishment of Syarikat Takaful Malaysia in 1984. The growth of the financial markets in Malaysia put a strong case forward for a more focused development of Islamic capital market products and services as a niche market in Malaysia (Securities Commission, 2004).
} 
Exhibit 1 Syariah-Based Unit Trust Funds (SC Annual Report 2004 - 2007)

\begin{tabular}{|c|c|c|c|}
\hline & 31 July 2007 & 31 July 2006 & 31 July 2005 \\
\hline No. of Management Companies* & 39 & 37 & 36 \\
\hline No.of Approved Funds* & 478 & 402 & 340 \\
\hline Total Approved Fund Size* & 411 billion units & 318 billion units & 267 billion units \\
\hline Units in Circulation & 181 billion units & 151 billion units & 139 billion units \\
\hline No. of Accounts & $11,607,816$ & $11,147,070$ & $10,860,675$ \\
\hline Total Net Asset Value (NAV) of Funds & RM 153 billion & RM 113 billion & RM 98 billion \\
\hline KLSE Market Capitalisation & RM 1077 billion & RM 769 billion & RM 695 billion \\
\hline$\%$ of NAV to KLSE Market Capitalisation & $14.16 \%$ & $14.72 \%$ & $14.17 \%$ \\
\hline
\end{tabular}

*Includes funds approved but not yet launched

Source: Annual Reports Security Commission

\section{THE PESSIMISTIC VIEWPOINT}

A central question in Islamic equity investment relates to a pessimistic view about the performance of Syariah-compliant stocks which have generally underperformed when compared to conventional stock (nonSyariah-compliant) performance. This pessimistic view is based on the fact that Syariah-compliant stocks or companies experience limited economic activity for two reasons. First, Syariah restrictions limit a companies' ability to use external sources of financing and this limit reduces the companies' sustainable growth. ${ }^{8}$ Second, Syariah restrictions limit investment opportunities so the companies' income potential is potentially reduced. Further, the higher cost of financing for Syariah-compliant companies will lead to a higher discount rate in investment project evaluation and fewer capital investments (Mazilan, 2001). This pessimistic view is further supported by Michelson, et al. (2004) who argue that moral considerations would introduce inefficiency in investment decisions by reducing the number of investment options and would increase either risk or reduce profitability of the portfolio and make the Syriah-compliant portfolio less efficient than conventional portfolios.

If these pessimistic views hold true, investors would not include Syariah-approved stocks in their investment portfolios. If the demand for Syariah-approved stocks is low, it suggests that the inclusion-exclusion exercise of KLSE Syariah Index components would not be treated as important information to investors. Thus, the stock price and trading volume of the stocks involved in the inclusion-exclusion exercise will not change. What matters is the perception that Syariah-approved stocks produce lower returns and a portfolio consisting Syariahapproved stocks will yield lower returns. In other words, it makes no difference to investors whether particular stocks are included in or excluded from the KLSI because Syariah-approved status does not convey information useful to differentiate good investment opportunities. This assumption suggests that the news on the inclusion in and exclusion from the KLSI will not affect the investors' perception about the companies and will have no impact on the behavior of stock prices and trading volume of the companies.

\section{THE SYARIAH VIEWPOINT}

Another view concerns the type of investors in the market. Customers choosing Syariah-approved stocks can be broadly divided into two groups. The first group comprises Muslims who opt for Syariah-approved investments because of the Quranic prohibition against riba, alcohol, uncertainties, and gambling. Their investment decisions are based solely on their religious consciousness and not solely on investment returns. Syariah based investment decisions are an indication of the investors' displeasure against Riba and their fear for God's punishment.

“O, believers, fear Allah, and give up what is still due to you from Riba if you are true believers.” (Verse 2: 278)

"If you do not do so, then take notice of war from Allah and His Messenger. But, if you repent, you can have your principal. Neither should you commit injustice nor should you be subjected to it." (Verse 2: 279)

\footnotetext{
${ }^{8}$ Sustainable growth is the maximum growth rate possible with existing financial policies and no external funding.
} 
Syariah based investors pay very close attention to the news on the inclusion-exclusion exercise to update their investment portfolio components. These investors will buy any new potential Syariah-approved stocks and sell all the non-Syariah-approved stocks even if the stocks promise good returns. The inclusion-exclusion exercise of Syariah-approved stocks may be interpreted as good (Syariah-approved) or bad information (non-Syariah-approved) that would affect the investors' expectations and therefore, the share prices and trading volume of the companies.

The second group of investors following the inclusion-exclusion exercise contains both Muslims and nonMuslims who have opted for Syariah-approved stocks not out of any religious scruple but because of better returns on investment. This group of value investors is not concerned with whether the returns are permissible or not permissible by Islamic law. This suggests that the inclusion-exclusion exercise of Syariah-approved stocks may not be interpreted from religious consciousness but from the perspective of good returns and poor returns and the image that comes together such as the certification as Syariah-approved stocks and being the component of an index (KLSI). The news on the inclusion-exclusion exercise only bridges the gap between the information that is held by the investors and the companies. The inclusion-exclusion exercise is believed to affect the investors' expectations and the share prices and trading volume of the companies that are added to or excluded from the Syariah approved list.

\section{THE CERTIFICATION OF SYARIAH-APPROVED STOCKS}

The certification of Syariah-approved securities has become a strategy of increasing importance to Malaysian companies to keep their present investors and to increase the market for their shares among non-Syariah based investors. Attracting non-Syariah based investors depends on the image of the Syariah-compliant inclusion, on the quality of the business operation, and on the product. This is most likely because Muslims, especially, and the public in general are becoming more discerning about investment returns and these investors tend to patronize companies that are Syariah-compliant and that offer quality goods and services. The companies that are Syariahcompliant and offer higher quality products and services enjoy greater profits than companies that do not follow these competitive strategies.

O'Rourke (2002) further suggests that by offering an ethical or sustainable product ${ }^{9}$ which has the potential to influence so many stakeholders - the financial industry is in a unique position to guide change towards corporate sustainability. O'Rourke (2002) concludes that Ethical Investment expresses different models of 'sustainability', of 'environment', of 'responsibility' and of 'ethics' in both its overall message of the fund - and the way in which the screening methods are designed and applied. Blumberg, et al. (1997) and Bercicci, et al. (2001) show that ethical investment techniques are a good way to recognize companies which may be currently under-valued and represent a good investment opportunity. Emphasizing ethical behavior is seen as having the potential to shift corporate behavior towards more sustainable patterns of production and consumption. This may suggest that the certification of being Syariah-approved stocks made by the SAC of SC delivers positive information and not being certified as Syariah-approved stocks delivers negative information to investors which could affect their expectations and, therefore, the share price and trading volume of the company.

\section{INFORMATION ASYMMETRY AND THE ISLAMIC CAPTIAL}

Without the certification of Syariah-approved securities from the SAC, investors especially Muslims and the public in general have no reference in which to make their investment decisions. There is often great asymmetry between information that is available to companies and information that is available to investors, with regard to what is permissible in Islam (halal) and the quality of the products that are offered on the market. According to Akerlof (1970 cited in Nayyar, 1990), when there is asymmetry in information about quality, products of both high and low quality could coexist in the market, which induces consumers to make an ad hoc evaluation of the quality of the products that they wish to purchase, resulting in a difficult and sometimes costly task. Information about the inclusion-exclusion exercise is believed to bridge the gap between information known to companies and information known to investors. Investors are expected to make wise decisions based on the information publically available and these decisions would affect the stock price and trading volume of the stocks involved in the inclusion-exclusion exercise.

\footnotetext{
${ }^{9}$ These would be stocks that do not operate in sectors such as tobacco, alcohol, gambling, and weapon manufacturing.
} 
Malaysian Muslim investors make up approximately $60 \%$ of the total population which underlines the high growth potential of the Syariah-based market segment. Globally the Syraiah based market is estimated at US\$800 billion of capital belonging to Muslim individuals and institutions that is invested in conventional banks globally due to limited and insufficient guidance on the compliance of capital market products with Syariah principles (Securities Commission, 2004). Thus, the certification of Syariah-approved financial products by the SAC would fill the gap and provide guidance to public investors locally and internationally on the Syariah-approved investment opportunities available in the Malaysian equity market. It is believed that the inclusion and exclusion of stocks from the KLSI would provide positive or negative information which could affect investors' expectations and the share price of the companies involved. Rational investors should use all publically available information and the SAC Syariah-approved certification is the key information to determine stock prices and is the central issue of the efficient market concept as suggested by Fama (1970).

Companies which consider the lawfulness and the quality of their products a priority should try to reduce the asymmetry of information publically available to the consumer. Syariah-approved certification by the SAC should help to reduce the asymmetry commonly seen in information in the market and to secure an advantage over competitors who disregard the value of this Syariah-approved certification. This suggests that the publication of news related to a firm's Syariah-compliant status, may well be interpreted by the stock market as positive investment news on the part of the company, which could affect the investors' expectations and therefore, the share price of the company.

Given the significance of Syariah-approved stocks news by the SAC of SC to the equity market in Malaysia, examining the impact on stock price and trading volume behavior around announcement time would provide further insights into investors' trading activities in response to the news release. At the same time, the efficiency of the stock market can be determined. It is essential to determine impact of the inclusion-exclusion information on stock market efficiency since the news release affects decisions on Syariah-approved stocks in which the selection criteria is based on Islamic Law. As suggested by Fama (1970), if the sock market reacts efficiently and investors behave rationally, share prices should reflect all the information affecting the results of the company and particularly information related to the Syariah-compliant certification. Stock prices will change only when the arrival of new information causes investors' expectations to be revised. A market is efficient with respect to a particular information set if it is impossible to make an economic profit by trading on the basis of that information set (Jensen, 1978).

\section{COMPONENTS OF KLSE SYARIAH INDEX (KLSI)}

As a market barometer for Syariah-compliant stock performance, movement of the KLSI is monitored by Muslim investors especially and the public in general in making investment decisions. Stocks which make up the Syariah-compliant component of the index are hypothesized to be treated more favorably by Syariah-based investors and Syariah-compliant stocks will become more liquid. Such listing is expected to increase the market liquidity of the stock and add to its prestige (Reily and Norton, 2006). As for the KLSI, the fact that there are significant numbers of Islamic conscious retail and government-linked institutional investors in the exchange would make the index more attractive to investors, (Zamri Ahmad et al., 2003).

KLSI has sufficient representation across sectors and has a high concentration in "Real Economy productive economy" and "New Economy - contemporary developments in business and the economy". Sectoral growth increases with growth in the "Real Economy" of the conventional sectors since inception in 1999 and since the launch of the Syariah Index, trading volume tracked the KL Composite Index and Emas Index quite closely and demonstrated more liquidity (Mamat, 2002). The recent development in Islamic finance and banking operations and the acceptance of Islamic finance and banking by the world market show that Syariah-based businesses can be considered as part of the new economy. News related to inclusion in and exclusion from the KLSI may be interpreted as important information and could affect the investors' expectations and the share price of the company.

To support the development of this Islamic equity market, the Malaysian government has the Malaysian capital market master plan (2001) and one of the objectives of this plan is to establish Malaysia as an international Islamic capital market centre. One of the strategic initiatives of the master plan is to create a viable market for the 
effective mobilization of Islamic funds and to promote awareness of the Malaysian Islamic capital market at the domestic, regional, and international levels. Investors across the globe can take a more active interest in Islamic investment ${ }^{10}$ and can be made aware of changing trends in investments according to Islamic Syariah. Fund managers, especially unit trust companies, are getting more interested in forming investment portfolios consisting of Syariah-approved financial instruments. These fund managers follow the Syariah-compliant stocks inclusion in and exclusion from the Syariah Index composition.

Awareness of Syariah-compliant status is necessary to mobilize funds from the Muslim population as their awareness of religious obligation is growing, especially in the area of investments as suggested by Nor Azuddin and Hasimi, (2002). According to Nor Azuddin and Hasimi (2002) the majority of unit trust companies in Malaysia, both state-run and privately-owned, provide Islamic-based trust funds as alternatives for the investing public and this has resulted in a new form of investment merging in Malaysia. From observations made on the list of updated Syariah-approved stocks from 1999 to 2005, a few counters have made tried to be included in the index after being excluded from the index. This shows that being included in and excluded from the KLSI has an impact on the companies' image and if the argument above is correct, being included in and excluded from the KLSI would give positive and negative news, respectively, to the stock prices and trading volume of the counters involved in the screening process. Otherwise, there should be no positive or negative impact to these stocks.

Therefore, being a component or not of the KLSI would bring an impact on investors' expectations and would impact upon the share prices and trading volume of the companies. If the inclusion-exclusion exercise does have an impact on investors' expectations, it can further provide evidence to support the success of the Malaysian Islamic equity market to stimulate awareness and interests toward investment in the Syariah-approved stocks.

\section{SUMMARY AND CONCLUSIONS}

It is pertinent to observe that Islam is not alone in prohibiting Riba and uncertainties in business dealings. The majority of ancient philosophers and Greek and Roman thinkers forbade interest in their day. The Old and the New Testaments similarly prohibited interest. The logic as to why religions, including Islam, have prohibited interest is that it exerts disastrous effects on human societies by reinforcing the tendency of wealth accumulation in fewer hands (Ayub, 2007). To the close followers of their own religions, the elements of prohibitions especially in business trading are simply a matter of ritual obedience, therefore, it should be taken as prohibited and it is not necessary to know the rationale. Thus, the individual and institutional investors' reactions to the inclusion-exclusion exercise of Syariah-approved stocks from the Kuala Lumpur Syariah Index (KLSI) are bounded by their religious belief. As a result of that, it is expected that the stock price and trading volume of the included and excluded stocks react positively and negatively, respectively.

On the other hand, the other theories and perceptions (information asymmetry, component of the index) on the reaction of stock price and trading volume of the included and excluded stocks from the KLSI are based on future returns and the financial soundness of the companies involved in the inclusion-exclusion exercise. Thus, if the stock price and trading volume of the stocks involved react, it is only a coincidence and not because of their obedience to the teaching of their religions. In conclusion, the term Syariah Index simply refers to a state of affairs wherein the financial institution and the individual investors have the choice to fulfill the relevant principles of Islamic jurisprudence. The only potential source of information comes from the Syariah Advisory Council of the Securities Commission's selection criteria. Thus, the reaction of the stock price and trading volume of the stocks involved in the inclusion-exclusion exercise is simply the effect of humans' behavior or perceptions and belief in their daily business trading.

\footnotetext{
${ }^{10}$ It is understood that the size of Islamic funds is currently worth between US\$200-500 billion managed by more than 200 Islamic institutions in 75 countries and which is predicted to register a growth of between 10-15\% annually (SC Newsletter, 2004).
} 


\section{AUTHOR INFORMATION}

Carl B. McGowan, Jr., PhD, CFA is a Professor of Finance at Norfolk State University. Dr. McGowan has a BA in International Relations (Syracuse), an MBA in Finance (Eastern Michigan), and a $\mathrm{PhD}$ in Business Administration (Finance) from (Michigan State). From 2003 to 2004, he held the RHB Bank Distinguished Chair in Finance at the Universiti Kebangsaan Malaysia and has taught in Cost Rica, Malaysia, Moscow, Saudi Arabia, and The UAE. Professor McGowan has published in numerous journals including Applied Financial Economics, Decision Science, Financial Practice and Education, The Financial Review, International Business and Economics Research Journal, The Journal of Applied Business Research, The Journal of Diversity Management, The Journal of Global Business, The Journal of Real Estate Research, Managerial Finance, Managing Global Transitions, The Southwestern Economic Review, and Urban Studies.

Junaina Muhamad holds a B.Sc. in Business Administration (Finance) and an MBA (Financial Management) from California State University, USA. She receives her Doctor of Business Administration (DBA) in Finance from University Kebangsaan Malaysia. Since 1998, Junaina has been a full-time lecturing at the Faculty of Economics and Management, University Putra Malaysia, teaching Finance, Islamic Finance and Banking subjects. Junaina's research interests are on Islamic Financial and Capital Market Management, Banking and Derivatives.

\section{REFERENCES}

1. Ahmad, Z., Ibrahim, H., \& Zainuddin, Y. 2003. The impact of delisting from KLSE Syariah Index. The Journal of Accounting, Management, and Economics Research 3(2): 109 - 118.

2. Akerlof, G. 1970. The market for 'lemons': Quality uncertainty and the market mechanism. Quarterly Journal of Economics 84(3): 488 - 500.

3. Atta, H. 2000. Ethical Rewards. An examination of the effect of Islamic ethical screens on financial performance and of conditioning information on performance measures. MSc. Dissertation, Department of Economics and Finance, University of Durham

4. Ayub, M. 2007. Understanding Islamic Finance. Wiley Finance Series.

5. Banz, R.W. 1981. The relationship between return and market value of common stocks. Journal of Financial Economics 9: 3 -18.

6. Barontini, R. \& Rigamonti, S. 2000. Working paper series at University Cattolica del S.Cuore, Via Necchi, Milano, Italy: $1-23$

7. Beaver, W. 1968. The information content of annual earnings announcement. Journal of Accounting Research $3: 67-92$

8. Blume, E., Easley, D. \& O'hara, M. 1994. Market statistics and technical analysis: The role of volume. Journal of Finance 49: $153-181$.

9. Brealy, R. A. 2000. Stock prices, stock indexes \& index funds. Bank of England Quarterly Bulletin : 61 68

10. Chan, H.W. \& Howard, P.F. 2002. Additions to an deletions from an open-ended market index: Evidence from the Australian All Ordinaries. Australian Journal of Management 27(1): 45 - 74.

11. Dhillon, U. \& Johnson, H. 1991. Changes in the Standard and Poor's 500 List. Journal of Business $64: 75$ $-85$

12. Dimson, E. \& Marsh, P. R. 1983. The stability of UK risk measures and the problem of thin trading. Journal of Finance 38: $753-783$.

13. Elayan, F., Li, W. \& Pinfold, J. 2000. Price effects of changes to the composition of New Zealand share indices. Working paper series at department of commerce, Massey University at Albany, Auckland, New Zealand.

14. Elayan, F., Li, W., \& Pinfold, J. 2001. Price effects of changes to the composition of New Zealand share indices. The New Zealand Investment Analyst 21: 25 -30.

15. Etzioni, A. 1988. The moral dimension. New York: The Free Press

16. Fama, E. 1970. Efficient Capital Markets: A Review of Theory and Empirical Work. Journal of Finance 25 (2) : $383-417$

17. Hegde, S. P. \& McDermott, J. B. 2003. The liquidity effects of revisions to the S\&P 500 index: an empirical analysis. Journal of Financial Markets 6: 413 - 459. 
18. Jain, P. 1987. The effect on stock price of inclusion or exclusion from the S\&P 500. Financial Analysts Journal 43: 58- 65.

19. Jensen, M. C. 1978. Some anomalous evidence regarding market efficiency. Journal of Financial Economics 6: 95 - 101

20. Kaen, F. R., \& Tehranian, H. 1990. Information effects in financial distress. The case of Seabrook Station. Journal of Financial Economics: 143 - 171

21. Karim, R. A. 2001. International accounting harmonization, banking regulation, and Islamic banks. The International Journal of Accounting 36: $169-193$

22. Lian, K. K., Chen, W. Y. \& Fah, T. L. 2005. Stock price effects of inclusion in and exclusion from the Kuala Lumpur stock exchange composite index. Paper presented at Malaysian Finance Association (MFA), Kuala Terengganu, Terengganu : $98-108$.

23. Mamat, A. R. 2002. Syariah Index - A Performance Indicator. A seminar paper presented at Securities Commission's Saturday Seminar, $30^{\text {th }}$. March, 2002, Kuala Lumpur.

24. Mazilan, M. 2001. The performance of Syariah-approved stocks of KLSE: a comparative study. Paper presented at IKIM, 13 - 14 February, 2001.

25. Markowitz, H. 1952. Portfolio selection. Journal of Finance 7(1) : 77 -91

26. Michelson, G., Wailes, N., Van der laan, S. \& Frost, G., 2004. Ethical investment processes and outcomes. Journal of Business Ethics $52: 1$ - 10

27. Mohd Hasimi, Y. \& Noor Azuddin, Y. 2002. Portfolio formation using Islamic-approved stocks in Malaysia. Capital Markets Review, KLSE and RIIAM : $67-86$

28. Nayyar, P. R. 1990. Information asymmetries: A source of competitive advantage for diversified service firms. Strategic Management Journal 11 : 513 - 519.

29. Nicolau, J.L. \& Sellers, R. 2002. The stock market's reaction to quality certification: Empirical evidence from Spain. European Journal of Operational Research 142: 632 -641.

30. O'Rourke, A. 2003. The message and methods of ethical investment. Journal of Cleaner Production 11: 683-693.

31. Reilly, F.k. \& Norton, E.A. 2006. Investments seventh edition. International student edition, Thomson South-Western, Canada

32. Rosly, S. A. \& Zabidi, A. M. 2002. Investment based on Syariah Principles. A seminar paper presented at Securities Commission's Saturday Seminar, $30^{\text {th }}$. March, 2002, Kuala Lumpur.

33. Rosly, S. A. 2005. Critical issues on Islamic banking and financial markets. Dinamas Publishing, Kuala Lumpur. ISBN 983-4289-03

34. Webley, P., Lewis, A., \& Mackenzie, C. 2001. Commitment among ethical investors: An experimental approach. Journal of Economic Psychology 22: 27-42. 
NOTES 